\title{
Household and meals versus the Temple purity system: Patterns of replication in Luke-Acts
}

\author{
J H Elliott \\ Visiting Professor, Faculty of Theology (Sec A) \\ University of Pretoria \\ University of San Francisco, San Francisco, CA
}

\begin{abstract}
In Luke-Acts the social codes and concepts associated with food and meals replicate and support the contrasting social codes, interests, and ideologies associated with the Jerusalem Temple, on the one hand, and the Christian household, on the other. In this study the thesis is advanced that in contrast to the Temple and the exclusivist purity and legal system it represents, Luke has used occasions of domestic dining and hospitality to depict an inclusive form of social relations which transcends previous Jewish purity regulations and which gives concrete social expression to the inclusive character of the gospel, the kingdom of God, and the Christian community.
\end{abstract}

\section{INTRODUCTION}

In a recent essay on 'Temple versus Household in Luke-Acts: A contrast in social institutions' (Elliott 1991:88-120), I have argued that in the Lucan economy of salvation the Jerusalem Temple and the household represent opposed types of social institutions and economic relations, only one of which, the household, according to Luke, is capable of embodying socially and ideologically the structures, values and goals of an inclusive gospel of universal salvation. The Temple institution constituted the hub of Jewish political, economic, social and religious power, the center of

- Prof John H Elliott, Professor of Theology and Religious Studies at the University of San Francisco, visited South Africa during June and July 1990 as HSRC Research Fellow of prof A G van Aarde of the University of Pretoria. His contribution Household and meals versus the Temple purity system: Pattems of replicotion in Luke-Acts will also appear in Biblical Theology Bulletin 21 (1991). 
an economic redistributive system whose exploitative management had led to oppression, peasant servitude, resistance, revolt and ultimately divine condemnation Reinforced by a self-serving interpretation of the Mosaic law and an exclusivist purity code, this system was opposed to and opposed by Jesus and was committed to the eradication of the Jesus movement. By contrast, the household, according to Luke, constituted the organisational center and ideological focus of the Jesus movement. It was the locale of the proclamation and acceptance of the gospel, healing, repentance, faith, generosity, mercy and the sphere of the Spirit's presence. The domestic features of reciprocal household relations, kin-like solidarity, hospitality and mutual support contributed toward the unity and vitality of the Jesus movement and provided the chief metaphors for describing the nature of life in the kingdom of God. In the course of Luke-Acts, the household gradually replaces the Temple as the scene and symbol of divine action, salvation, and human community.

In this study, I shall take these conclusions a step further and attempt to show how in Luke-Acts the social codes and concepts associated with food and meals in particular replicate and support the contrasting social codes, interests and ideologies associated with the Jerusalem Temple and the Christian household in general. My thesis is that in contrast to the Temple and the exclusivist purity and legal system it represents, food and meals, together with their associated domestic relations, are used to depict an inclusive form of social relations which transcends previous Jewish purity regulations and gives concrete social expression to the inclusive character of the gospel, the kingdom of God and the Christian mission.

\section{DOMUS AND DIET}

In the Lucan narrative, domestic scenes, household relations and occasions of eating and dining are highlighted and closely related in several ways. More attention is given to both households and meals in Luke-Acts than in any other New Testament writing (Koenig 1985; Elliott 1991; Neyrey 1991b). Except for the feeding of the five thousand in a desolate locale (Lk 9:10-17) and the implied consumption of the Temple sacrifices (Lk 2:24; 13:1), eating and meals regularly and naturally take place in domestic settings. Conceptually, domestic relations, food, eating and dining are also associated. In Luke's account, it is occasions of hospitality and meals which present related dilemmas concerning appropriate modes of behaviour and social interaction. These occasions are used by Luke to illustrate the contrast between the perspectives and praxis of Jesus and his followers and adherents of the Temple purity system. Clean and unclean foods, meals and banquets, together with relations and behaviour in the household, serve in Luke-Acts as related foci and symbols for depicting the nature of Christian sociality and the standards of behaviour in the kingdom of God. 
From an anthropological point of view, this relation between diet and domus, food consumption and domestic comportment, is a cross-cultural commonplace. As a body of anthropological research now demonstrates, arrangements and norms concerning food and meals regularly relate to and replicate patterns and rules of social systems in general and familial institutions in particular (Douglas 1966, 1975, 1984:1-39; Leach 1969; Feeley-Harnik 1981:6-18; Powers \& Powers 1984; Harris 1985). Put briefly, food codes embody and replicate social codes. In any society or sub-group thereof, there is generally a correlation of the rules and boundaries concerning what one eats, with whom one eats, when one eats, how one eats, where one eats, to what community, group or kinship network one belongs, and what constitutes the group's traditions, values, norms and worldview. In ancient Greek, Roman and Jewish societies, as in contemporary cultures, there is a discernable correlation between the social patterns governing connubium and commensality, sex and sociality, food symbolism, domestic symbolism and cosmology.

In regard to food in particular, anthropologist Mary Douglas has proposed considering food as a code of social relations:

If food is treated as a code, the messages it encodes will be found in the pattern of social relations being expressed. The message is about different degrees of hierarchy, inclusion and exclusion, boundaries and transactions across the boundaries. Like sex, the taking of food has a social component, as well as a biological one. Food categories therefore encode social events...the ordered system which is a meal represents all the ordered systems associated with it.

(Douglas 1975:249, 273)

This is to say that beyond supplying nourishment, food and meals have a variety of social capacities. They can serve as social boundary markers distinguishing types and groups of participants and consumers: men/women, adults/children, humans/ gods/demons, kin/non-kin, upper/lower classes, insiders/outsiders. They can also serve as temporal and spatial markers distinguishing ordinary from extraordinary, profane from holy time and space. Beside marking status lines and social boundaries, food and meals are the media of social and economic exchange. Like the exchange of women in marriage or of other gifts and services across group boundaries, the sharing of food and hospitality plays an important role in the maintaining or modifying of social relations. Eating etiquette, like sexual etiquette and hospitality etiquette, replicates broader social codes aimed at securing order and social cohesion. Specific types of food (bread, wine, oil, meat, fish etc) and meals (daily food 
ingestion, private or public feasts, marriage banquets etc) also serve as ideational and ideological symbols of core beliefs and values. Thus, who may eat what with whom is a direct expression of social, political and religious relations' (Feeley-Harnik 1981:2). Food and meals encode social relationships, cultural values and norms and metaphysical worldviews (Douglas 1975:90-94).

In cultures where the external boundaries of the social system are regarded as under pressure, purity systems distinguishing between clean/unclean, pure/polluted food and persons may develop as a social mechanism for bolstering inadequate legal or moral structures (Douglas 1966:126-127). In this situation where the maintenance of the integrity (purity) of tribal or national identity is a major concern and the intermarriage of insiders and outsiders is seen to be a problem, there will tend to be a concomitant concern for the purity of what one eats and with whom one eats (Douglas 1975:86-90). Accordingly, codes defining social, sexual and food purity and pollution will form one unified complex of concerns. The concern for the purity of blood lines is replicated in a concern for the purity of food. Defensive marriage strategies correlate with defensive eating strategies.

This was the case for post-exilic Judaism, as evidenced by the Holiness Code of Leviticus 17-26. Ezra-Nehemiah, the Intertestamental Literature, Qumran, the New Testament and the Mishnah (see Douglas 1966, 1975; Leach 1969; Neusner 1973; Soler 1979; Belo 1981:37-59; Feeley-Harnik 1981; Malina 1981:84-121, 122-152; Newton 1985; Neyrey 1986; Esler 1987:73-86). Here an elaborate and conceptually coherent system of purity rules regulated the purity of pollution of animals and food, humans, their physical bodies, their activities and their associations, and the degrees of holiness of the Jerusalem Temple, the land of Israel, and Jewish society (Malina 1981; Neyrey 1986). Particularly in Pharisaic ideology, food and meals formed a mediating link between the Temple with its altar and the private home and its table. For the Pharisees, the rigorous purity regulations pertaining to the Temple, its priesthood and sacrifices, were extended to the bed and board of every observant Jew.

\section{TEMPLE PURITY SYSTEM CONTRASTED TO HOUSEHOLD}

This purity system, linked with the Temple and legitimated in the Mosaic law and the oral tradition of the Pharisees, constituted, according to Luke-Acts, that system with which Jesus and his followers ultimately came into unavoidable conflict. For Luke, as for Jesus, it was an exploitative institution which had lost its legitimacy and thereby failed to mediate union with the Holy One and the blessings of the kingdom. Consequently, we note in Luke-Acts not only a natural association of meals and households, but also a coherence in the teaching and practice of Jesus and his 
followers regarding both food and dining and kin and fictive kin interaction, and a consistent contrast between the values and strategies of the Jesus movement and those of the representatives of the Temple purity system. For Luke, the household, in contrast to the Temple, represents in its familial organisation and solidarity, its inclusive community of brothers and sisters under one heavenly Father, its social relations of mutual sharing, generalised reciprocity, generosity, mercy and justice, the sphere of the Spirit's presence and God's merciful reign. It is precisely these characteristics of domestic relations in general which are illustrated and stressed in the Lucan accounts concerning meal and food codes in particular. Within the Lucan narrative, a new food code replicates and supports a new social code, a code consonant with a new vision of an inclusive salvation and an inclusive community of the redeemed.

\section{HOUSEHOLD AND HOSPITALITY}

For Luke, the household was, historically, the social basis and focus of the Jesus movement and the Christian worldwide mission. The church spread across the Mediterranean world from household to household. At the same time, the household and its domestic relations likewise provided the movement with its main model of organisation, behaviour and self-identification. Kinship provided the model for fictive kin relations of 'brothers and sisters in the faith' under one heavenly Father. In this community of kin and fictive-kin, social relations were intimate, inclusive and governed by the reciprocity characteristic of family and friends. Resources of food and shelter were shared directly according to availability and need (Lk 6:3-36; 11:5$13 ; 12: 33 ; 15: 3-32 ; 18: 22 ; 19: 1-10 ;$ Ac $2: 44-47 ; 5: 32-37 ; 6: 1-6)$. No holy place or hierarchy set standards for social differentiation or discrimination because in the brotherhood of the faithful all was holy (Lk 11:4-41; Ac 10:1-11:18; 5:9), and all persons were equally servants (Lk 17:7-10; 22:24-27). Humility (Lk 14:7-11; 18:14) rather than elitism, inclusivity (Lk 14:12-24; Ac 10:1-11:18) rather than exclusivity, consensus (Ac 2:42; 4:32) rather than constraint, personal commitment (Ac 3:11-16; 4:8-12; 5:23-31) rather than abstract Temple and Torah allegiance was the rule. The private space of house and home was the scene where hospitality, generosity, friendship, deeds of mercy, acts of mutual aid and comfort, familial love and fraternal support, unmeasured and unlimited, welded bonds of intimacy and solidarity. Here the honorable person was the generous one who had given all away (and so was wealthy beyond measure in social prestige and honor before God - Lk 12:33-34; 18:22; $21: 1$ 4).

The reciprocities of household relations are particularly evident in Luke's stress on giving/forgiving/lending without expectation of return (Lk 6:30, 35; 7:41-42; 
$10: 29-37 ; 11: 4 ; 14: 12-14,15-24$; Ac $20: 35$ ) other than a future heavenly reward (Lk $6: 37-38 ; 12: 32-34 ; 14: 12-14,15-24 ; 18: 22)$. As ongoing rather than once-for-all activities, these interactions bound the partners in an open-ended and continuous relationship. This benevolence (mercy/alms) is intended especially for 'the poor, the maimed, the lame, the blind' ( $L k$ 14:13), those lost and lowly ones ( $L k$ 19:10), social deviants (tax collectors and sinners - Lk 15:2) and ethnic outsiders (Samaritans, Gentiles) to whom the gospel of Jesus was particularly directed (Lk 4:30; 12:33; 18:22; 19:8-9). Such deeds of mercy and justice/righteousness (Karris 1985: 23-78) are explicitly identified as the true purity ( $L k 11: 41$ ) which unites benefactors with both beneficiaries and their benefactor God (Lk 6:35-36; 12:29-34) and the Lord (Ac 10:38). Thus mercy rather than cultic purity is the essential bond uniting the people of God and their heavenly Father (Lk 6:36; cf Borg 1984:73-199).

Giving without expectation of return, hospitality and the sharing of food and shelter, care for the ill, generous support for those in need, forgiveness of debts and redemption of those in debt are all actions characteristic of kin groups and the ethos of the household. In Luke-Acts this pattern of domestic relations and the intimacy and solidarity it presumes, serves as the decisive model for the identity and ethos of the Christian community as a whole. This form of community ordered around the roles, relationships and responsibilities of the household stands in stark contrast to the exploitative system of the Temple, and embodies an alternate vision of salvation based not on cultic purity but on the gift of divine mercy and its imitation in the family of faith.

\section{FOOD AND MEAL CODES}

The textual evidence upon which this summary of the household is based includes virtually every reference to meals in the Lucan narrative. For Luke, meals, like domestic relations, function in three related ways. They represent (1) physical means for sustenance and survival, (2) channels and codes of sociality, and (3) symbols of life shaped by the principles and values of the kingdom of God. Dining scenes like domestic scenes, or dining events within domestic settings, describe the social engagements of Jesus and his followers, the inclusive scope of their association with the margined and outsiders and their practice of material aid and social support. These scenes also provide the scenarios and examples for teaching on purity and mercy, generosity and inclusive hospitality, acceptance of the lost and lowly, forgiveness, status reversal, humility and service - all aspects of life in the kingdom of God and the household of faith. The sharing of food and table-fellowship, like the reciprocal relations of kin and fictive-kin, symbolise social identity and solidarity, commitment and loyalty, submission or non-submission to Temple purity regula- 
tions, inclusivity or exclusivity, forgiveness or non-forgiveness, divine blessing and judgement. Meals thus serve in Luke-Acts as potent illustrations of the beliefs and behaviour of the new community called into being by Jesus and the Spirit (Moxnes 1986).

For Luke, the problems encountered by the Jesus movement concerning food and meals, the disputes concerning purity and the divergent positions assumed by the Jesus movement and its opponents are inseparably related to the problems, purity disputes and alternative positions concerning social relations in general. In regard to the food they eat, the persons with whom they associate and the values which govern the practice of both, Jesus and his followers break decisively with the Temple purity system and its adherents and embrace an alternative ideology according to which union with the Holy One is possible for all.

\section{ACTS 10:1-11:18: AN ILLUSTRATTVE CASE}

In all of Luke-Acts this contrast of correlated food codes and social codes, eating habits and domestic relations, is most directly apparent in a key episode of Acts recounting the interaction between the apostle Peter and the Gentile Cornelius (Ac 10:1-11:18). Here Luke relates how in the context of domestic hospitality and controverted purity rules concerning food and social interaction God rescinded previous purity norms, poured out his Spirit upon supposedly unclean Gentiles and thereby gave divine warrant to a mission to the Gentiles.

That we are dealing here with an episode of critical importance is evident from its length, its location and its thematic. Its sixty-six verses make it the longest narrative of Acts (Krodel 1981:40). In regard to the agenda and structure of Acts which concerns the geographical advance of the apostolic witness under the direction of the Spirit from 'Jerusalem, Judaea and Samaria to the end of the earth' (1:8), this pericope marks the advance of the messianic movement to Caesarea, the seat of Roman power in Palestine and, as a key transitional episode, sets the stage for themission to the Gentiles beyond the limits of the Holy Land (11:19). Thematically, this narrative presents, in tandem with chapter 15 , the most comprehensive statement in all of Acts concerning the social and religious dilemmas encountered by, and the divine warrant justifying, a universalist Jewish movement embracing both Jews and Gentiles.

For our purposes, there are four critical features of this narrative which merit attention. The first is the domestic setting of the action and the interaction of households in the spread of the gospel. This forms part of a recurrent theme of Luke-Acts according to which the Jesus movement advanced from household to household (Ac 9:11; 16:14-15; 17:5-7; 18:2-20;21:8; cf 28:7). Specifically, the house- 
hold of Simon the tanner where Peter resided (10:6, 17-18, 32; 11:11; cf 9:43) and the household of Cornelius which Peter and his companions visited (10:2, 22, 30; $11: 12,13)$ and whose members they baptised $(10: 48 ; 11: 14-17)$ figure repeatedly and prominently in the story. The story moves back-and-forth between the house of a Gentile (Cornelius) and that of a Jew (Simon), Cornelius' vision at home and Peter's vision at home, and Cornelius' offer and Peter's acceptance of domestic hospitality. In this reciprocal exchange of hospitality, Simon the tanner is Peter's host (9:36; 10:6, 17-18, 32; 11:11), Peter (and Simon) are hosts to Cornelius emissaries (10:17-23a), and Cornelius (and his household) play host to Peter and his companions (10:24-48; 11:3, 12-17). For the Gentile family of Cornelius, like the company of Jews at the first Pentecost (2:1-42), it is a house where the Holy Spirit and the speaking in tongues is experienced $(2: 2 ; 10: 44-47 ; 11: 15)$ and it is the household of Cornelius which is baptised and saved $(10: 48 ; 11: 14-17)$. Most importantly, it is the occasion of domestic hospitality, social association and commensality which posed the problem over which Peter and the circumcision party struggled (11:2-3): 'Why did you go to uncircumcised men and eat with them?'

The second and third elements of the narrative to be noted concern the specific problems it addresses: the problem of the social association of the Jesus movement with Gentiles, the problem of clean/unclean food consumption and the question of the norms by which such problems are to be adjudicated. These issues constituted pressing dilemmas for the nascent Jesus movement and are reflected frequently throughout Luke-Acts, though it is here that they receive their most extensive attention. An analysis of the precise manner in which Luke addresses these related issues will involve a consideration of a fourth and final ingredient of this narrative, namely the correlation of codes regulating food and eating on the one hand and social association on the other, that is, the relation of the norms governing commensality and community.

At the heart of this episode lay a fundamental controversy within the Jesus movement over the ethnic boundaries of the Jesus movement and the continuing validity of conventional Jewish purity rules as standards of behaviour. Acts 10:111:18 is Luke's attempt to give this problem literary, social and theological expression. The specific terms of the controversy are mentioned only toward the close of the story (11:1-3) and are set within a narrative framework which conveys Luke's own theological and social point of view. Thus the conflict itself is preceded by a series of interwoven accounts repeating how, under God's direction and against Peter's initial resistance, the apostle was led to declare and manifest to Gentiles, Cornelius and his household, that God shows no partiality or discrimination, that Peter should therefore accept Cornelius' hospitality, and how, in response to Peter's 
proclamation, this God-fearing and believing Gentile household was the recipient of the outpouring of the Spirit, forgiveness and baptismal incorporation into the community of Christ. Thereupon follows the account of the conflict: 'Now the apostles and the brothers who were in Judaea heard that the Gentiles also had received the word of God. So when Peter went up to Jerusalem, the circumcision party [i e believing Jews insisting on strict Torah and purity observance] criticised him, saying, "Why did you go to uncircumcised men and eat with them?"' (11:1-3).

Implicit in this accusation are Jewish purity norms perceived as having been violated by Peter, norms prohibiting Jews from associating with uncircumcised and hence 'unclean' persons and from eating the unclean food which they presumably serve. The accusation explicitly links the code governing eating with the code regulating social associations and the relations of domestic hosts and quests. The fact that Luke himself is aware of and, indeed, highlights this linkage is also evident in the events preceding the conflict.

The issue of purity is raised early in the story in the account of Peter's vision (10:9-16) and is repeated as part of Peter's response to the accusation (11:4-10). Here the issue initially was one of unclean animals or food which the Lord commanded Peter to sacrifice and eat. Twice it is stated that Peter objected with the words, 'No, Lord; for I have never eaten anything that is common or unclean [kot-

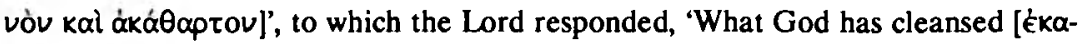

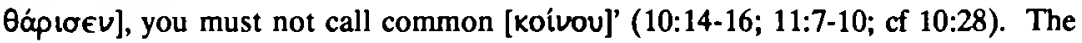
meaning of the vision at first was perplexing to Peter (10:17) but promptly became clear. Immediately following the vision, and while Peter was pondering its meaning, the house where Peter stayed was visited by emissaries from the unclean Gentile Cornelius requesting Peter to come to his house (10:17-23). According to the direction of the Spirit telling him to go with them 'making no distinction' (10:19-20; 11:12), Peter invited these unclean Gentiles into his house (10:23a) and then accompanied them to the unclean house of Cornelius (10:23b-24). In Cornelius's house and among his family and friends, Peter repeated his scruples about purity observance, now in regard to unlawful association with Gentiles: 'You yourselves know

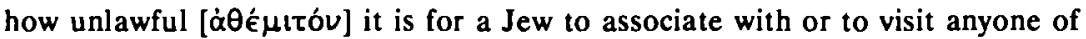
another nation [ $\dot{\alpha} \lambda \lambda \propto \phi \hat{u} \lambda \omega]$. But God has shown me that I should not call any per-

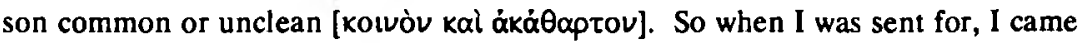
without objection' (10:28-29).

The implication of Peter's remark is that the purity codes concerning unclean food and unclean persons are related and that God's instruction that what God has cleansed, you must not call common' $(10: 15 ; 11: 9)$ pertained both to food and persons, eating and associations. The connection is made explicit in the identical terms, 


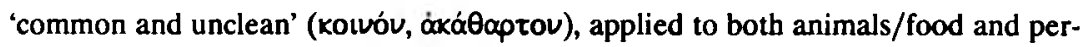
sons $(10: 14,28 ; 11: 9)$. Directly connected to this realisation on Peter's part is the further perception that 'God shows no partiality [discrimination], but rather in every nation any one who fears him and does what is right is acceptable to him' (10:34-35). Accordingly, Jesus Christ, the evangelist of the good news of peace, is the Lord of all, and everyone who believes in him receives forgiveness of sins through his name $(10: 36,43)$.

In this narrative it is the controversy over purity/impurity which most graphically illustrates the general Lucan contrast of Temple and household institutions. In accord with divine revelation, an exclusivistic Temple purity code concerning food, persons, ethnic and geographical boundaries is superseded within the framework of domestic reciprocities by an inclusive dietary and social code consistent with an inclusive concept of divine salvation and human community. In this connection two further subtle features of the story may also be noted. Firstly, it is at Simon's house, not the Temple, that the apostle is commanded by God to 'sacrifice and eat' (日voov kai фáye; 10:13; 11:7). In contrast to the Temple regulations requiring the sacrifice of only clean animals, Peter is commanded by God to sacrifice and eat what is seemingly unclean. Secondly, Cornelius, likewise in his house, is visited by an angel assuring him that 'your prayers and alms have ascended as a memorial before God' $(10: 4 ; 10: 31$; cf $10: 2)$. The reference to 'as a memorial [ $\mu$ múóouvov] before God' has cultic overtones recalling the sacrifices of the Temple offered 'as a memorial' (before God) (Lev 2:1-3; cf $2: 9 ; 5: 12 ; 6: 15$ ). The implication is that Cornelius's prayers and alms in his home are equivalent to or a replacement of the 'clean' sacrifices at the Temple. This echoes the earlier word of Jesus directed to the Pharisees in Luke 11:41: 'Give for alms those things which are within; and behold, everything is clean for you.' (For the association of alms, purity and Temple see also Ac 24:17. 18.) Deeds of mercy (alms) and prayer now take the place of Temple sacrifice as the sign of union with God.

For the narrative as a whole and for the controversy specifically, the principle is established that whereas the circumcision party discriminated in regard to both food and persons, God and God's witness do not. As God shows no partiality and does not discriminate (10:34-35) regarding either food or persons, so his witnesses are to act $(10: 15,28-29 ; 11: 9,12$; cf 10:20; 11:17; Lk 6:35-36). As Luke has already indicated earlier, the God who cleanses food also cleanses persons ( $L k$ 4:25-27, 31-37; $5: 12-16 ; 6: 18 ; 7: 22 ; 8: 26-39 ; 9: 42 ; 11: 14,18-20,24 ;$ Ac $5: 16 ; 8: 7)$. The former Jewish code regarding social association and domestic relations, replicated in the code concerning food and eating, has been annulled by none other than God himself. His initiative and direction is evident throughout the story from start to close: in the 
parallel visions of a Gentile $(10: 1-8,30-32)$ and a Jew $(10: 9-16,17 ; 11: 4-10)$, the angel's appearance to both $(10: 3,22,30 ; 11: 13)$, the divine voice $(10: 13,15 ; 11: 7,9)$, the instruction of the Spirit $(10: 19-20 ; 11: 12)$, the outpouring of the Spirit on the Gentiles (10:45), the gift of tongues (10:46), and their baptism with the Spirit $(10: 47$; 11:15-17) paralleling the earlier spiritual baptism of the Jews at Pentecost (10:47; $11: 15-17)$, and the divine gift of repentance unto life (10:34-43; 11:18). Accordingly, the mission to the Gentiles, the break with the traditional Temple purity code regulating food and eating, domestic reciprocities exchanges between Jews and Gentiles, and the inclusive composition of the messianic community, Luke affirms, are not deviations from God's will but rather have divine warrant and blessing.

\section{SUMMARY AND CONCLUSIONS}

In the Peter-Cornelius episode we find confirmation of the thesis that, in Luke-Acts, over against the temple and the exclusivist purity and legal system it represents, domestic relations, food and meals involve for the Jesus movement an inclusive form of social relations which transcends previous Jewish purity regulations and gives concrete social expression to the inclusive character of the gospel, the kingdom of God and the Christian mission. The coherence of eating and social codes and of codes and ideology, which is evident here is consistent with the details of other dining and domestic scenes of the two-volume work (e g Lk 5:27-39; 7:36-50; 11:3752 ; 12:35-40, 41-48; 13:22-30; 14:1-14,; 15-24; 15:1-32; 17:7-10; 19:1-10; 22:17-38; 24:13-49; Ac 2:43-47; 4:32-37; 6:1-6; 15:1-29; 16:25-34; 20:7-12; 27:33-38; 28:23-29). This consistency illustrates the coherence of Luke's literary composition, social perspective and theological ideology.

This narrative plays a critical role in Luke's tracing the geographical advance and ethnic inclusivity of the mission as it moved from Jerusalem and Judaea to Samaria and the end of the earth. It highlights the key role played by households and the reciprocities of domestic hospitality in the formation of Christian social networks. It establishes the divine warrant for a new set of norms regulating Christian group identity, behaviour and boundaries. And it graphically illustrates the correlation of codes governing food and eating, domestic relations, spatial and ethnic boundaries and social identity. Here in one narrative Luke demonstrates the unity of the issues of communal inclusivity, commensality and the co-salvation of all who believe.

Meals and food, like the households in which they are consumed, illustrate a form of social relations at variance with the Temple purity system but sanctioned by the Holy Spirit. Both meals and domestic relations which cross ethnic and religious boundaries symbolise the new set of social relationships made possible by repen- 
tance and faith in Jesus Christ who is Lord of all. Our episode thus illustrates the phenomenon observed by anthropological studies of other ethnic groups that 'distinctive ethnic diets disappear at the same time as other ethnic boundaries disappear' (Douglas 1984:30).

In our story of the Gentile Pentecost, the contrast of Temple and household institutions comes to expression primarily in the controversy over the purity code and both the food and the social relations it regulates. Here the exclusivist principles and perspectives of the Temple purity code are represented by the circumcision party which insists on distinguishing and discriminating between clean and unclean food and persons. Peter, on the other hand, is directed by God to abandon this set of purity rules and to engage instead in the inclusive reciprocities of domestic hospitality on the basis of the principle that God does not discriminate and what God has cleansed no one should call common. Thus association and commensality with Gentiles in the Christian mission have divine warrant and blessing.

The controversy with the circumcision party over food and persons and its implication for the mission to the Gentiles breaks out anew, according to Luke, at a later convocation in Jerusalem recounted in Acts 15 . Once again the issue is the contrast in codes governing the purity of persons, food and behaviour (15:2, 5, 20, 29). And once again, the principle established in the Peter-Cornelius episode is reiterated by Peter: 'God who knows the heart bore witness to them [the Gentiles], giving them the Holy Spirit just as he did to us [15:8; cf 10:44-45; 11:15-18], and he made no distinction between us and them [15:9a; cf 10:34-35; 11:12], but cleansed their hearts by faith' (15:9b; cf 10:15, 28). Impartiality, repentance and faith, and imitation of God, not Temple purity rules, constitute the divinely sanctioned norms governing the identity, composition and behaviour of God's holy people.

Finally, consonant with this replications of food and social norms, we note a broader pattern of replications illustrating the severance of the Jesus movement from the constraints of the Temple purity system. The Church's crossing and abandoning of Jewish purity lines is illustrated by Luke in regard to territory, persons, social status, ethnicity and ideology. The Peter-Cornelius episode marks the transition of the Jesus movement from holy to unholy land, from holy to marginal to unholy persons and ethnic groups, and from an exclusive to an inclusive concept of holiness. Here the scene shifts from Joppa-by-the-sea on the territorial margin of Judaea. The action involves the association of holy persons (Peter and companions) with a socially marginal Jew (Simon the tanner plying an unclean occupation) and an unholy Gentile (Cornelius), who as a 'God-fearing' man is marginally associated with Judaism. The action likewise involves the interaction of representatives of a holy Ë $\theta$ vos with those of an unholy ë $\theta$ vos. And the issue at stake involves contrasting 
norms and ideologies concerning purity, food, commensality and communal identity. The story thus recalls an earlier narrative, Luke 8:26-39, containing a similar set of replications involving holy and unholy land (Galilee/Gerasa), persons (Jesus and disciples/demoniac with unclean spirit), food (unclean swine) and ethnic boundaries (Jews/Garasenes), and an event of divine cleansing (8:33, 39).

In sum, Luke's story of the Gentile Pentecost and God's sanction of a mission incorporating both Jews and Gentiles repeats and unites several major themes of his narrative: the household as the basis of that mission and the sphere of the Spirit's action, the divine revocation of previous purity rules governing land, persons, status, food, domestic relations and ethnic boundaries, and the inclusive nature of the community of those believing in Jesus the Lord of all and in God who shows no partiality. Through a complex web of replications involving food, social relations, boundaries and ideology, Luke here articulates the inclusive understanding of holiness, salvation and human community informing his work as a whole.

Works cited

Belo, F 1981. A materialist reading of the Gospel of Mark. Maryknoll: Orbis.

Borg, M J 1984. Conflict, holiness and politics in the teachings of Jesus. New York: Mellen Press.

Douglas, M 1966. Purity and danger: An analysis of concepts of purity and taboo. New York: Praeger.

--. 1975. Deciphering a meal, in Douglas, M, Implicit meanings: Essays in anthropology. Boston: Routledge \& Kegan Paul.

- (ed) 1984. Food in the social order: Studies of food and festivities in three American communities. New York: Russell Sage Foundation.

Elliott, J H (ed) 1986. Social-scientific criticism of the New Testament and its social world. Decatur: Scholars Press. (Semeia 35.)

-- 1991. Temple versus Household: A contrast in social institutions, in Neyrey, J H (ed), The world of Luke-Acts. Peabody, MA: Hendrickson Publishers. (Also HTS 47 [1991], 88-120.)

Esler, P F 1987. Community and gospel in Luke-Acts: The social and political motivations of Lucan theology. New York: Cambridge University Press. (SNTS Monograph Series 57.)

Feeley-Harnik, G 1981. The Lord's table: Eucharist and Passover in early Christianity. Philadelphia: University of Pennsylvania Press.

Harris, M 1985. Good to eat: Riddles of food and culture. New York: Simon \& Schuster. 
Karris, R 1985. Luke: Artist and theologian. New York: Paulist Press.

Koenig, J 1985. New Testament hospitality: Pantnership with strangers as promise and mission. Philadelphia: Fortress.

Krodel, G 1981. Acts. Philadelphia: Fortress Press. (Proclamation Commentaries.)

Leach, E 1969. Genesis as myth and other essays. London: Jonathan Cape.

Malina, B J 1981. New Testament world: Insights from cultural anthropology. Atlanta: John Knox.

Moxnes, H 1986. Meals and the new community in Luke. Svensk Exegetisk Arsbok 51-52, 158-167.

Neusner, J 1973. The idea of purity in ancient Judaism. Leiden: Brill.

Newton, M 1985. The concept of purity at Qumran and in the letters of PauL Cambridge: Cambridge University Press. (SNTS MS 53.)

Neyrey, J H 1986. The idea of purity in Mark's gospel, in Elliott 1986:91-128.

-.- (ed) 1991a. The world of Luke-Acts. Peabody, M A: Hendrickson Publishers.

--- 1991b. Ceremonies in Luke-Acts: The case of meals and table-fellowship, in Neyrey 1991a.

Powers, W K \& Powers, M M N 1984. Metaphysical aspects of an Oglala food system, in Douglas 1984:40-96.

Soler, J 1979. The dietary prohibitions of the Hebrews. New York Review of Books June 14, 24-30. (Reprinted in Forster, R \& Ranum, O [eds], Food and drink in history, 126-138. Baltimore: The Johns Hopkins University Press.) 